\title{
PROJETO DE ENGENHARIA DIDÁTICA: A AVALIAÇÃO DE PRÁTICAS DE LINGUAGEM EM FOCO
}

\section{DIDACTIC ENGINEERING PROJECT: FOCUS ON ASSESSMENT OF LANGUAGE PRACTICES}

\author{
Luiz Antônio Ribeiro* \\ Cláudia Mara de Souza** \\ Aurélio Takao Vieira Kubo***
}

\section{RESUMO}

Este artigo fundamenta-se nos pressupostos epistemológicos do Interacionismo Sociodiscursivo - ISD e focaliza o estudo dos gêneros textuais e sua relação com o ensino da língua/linguagem. O objetivo geral é investigar o desenvolvimento das capacidades de linguagem dos alunos a partir de instrumentos avaliativos aplicados no transcorrer da implementação de um projeto de engenharia didática. A orientação metodológica é a da pesquisa-ação, com vistas a produzir conhecimentos de uso efetivo no nível didático. Os resultados sinalizam o fortalecimento das interações entre professor, alunos e objetos de ensino; participação ativa e dialógica no cumprimento das atividades; e maior autonomia quanto ao funcionamento sociocomunicativo do gênero estudado.

Palavras-chave: engenharia didática; sequências didáticas; avaliação.

\section{ABSTRACT}

This paper is based on the epistemological assumptions of Socio-discursive Interactionism - SDI and it focuses on the study of textual genres and its relation to the language teaching. The primary objective is to investigate the development of the students' language abilities from the evaluation instruments applied during the implementation of a didactic engineering project. The action re-search methodological approach was selected to produce knowledge of valid use in the didactic level. The results indicate the strengthening of interactions between teachers, students and objects of study; active and dialogical participation in the accomplishment of the activities; and greater autonomy regarding the socio-communicative process of the studied genre.

Keywords: didactic engineering; didactic sequences; evaluation.

\footnotetext{
* Centro Federal de Educação Tecnológica de Minas Gerais (CEFET-MG), Timóteo (MG), Brasil. luiz.antonio.ribeiro32@gmail.com.

** Centro Federal de Educação Tecnológica de Minas Gerais (CEFET-MG), Timóteo (MG), Brasil. claudiaitab@gmail.com.

*** Centro Federal de Educação Tecnológica de Minas Gerais (CEFET-MG), Timóteo (MG), Brasil. aureliokubo@gmail.com.
} 


\section{INTRODUÇÃO}

No interior de uma psicologia da linguagem sustentada nos pressupostos epistemológicos do interacionismo social, um projeto de engenharia didática é a um só tempo uma metodologia de pesquisa e um instrumento para planejar as ações de ensino (DOLZ, 2016). Enquanto metodologia de pesquisa-ação, a engenharia didática situa o professor como o pesquisador responsável pelo planejamento, experimentação e avaliação de dispositivos didáticos. Enquanto instrumento para planejar ações de ensino, um projeto de engenharia didática permitirá ao professor ultrapassar a lacuna apontada por Black e William (1998, p. 31-32) quanto à apresentação de situações novas, que requerem dos alunos novas formas de refletir e empregar o conhecimento.

Consideradas essas duas dimensões, a pesquisa que originou este artigo interessa-se por mensurar o desenvolvimento das capacidades de linguagem. A hipótese inicial é a de que a criação e implementação de dispositivos de ensino, a aplicação de avaliações formativas e as mediações realizadas no âmbito da engenharia didática maximizam o desenvolvimento da aprendizagem. Assim, com o objetivo de verificar o desenvolvimento das capacidades de linguagem dos alunos a partir dos instrumentos avaliativos, o artigo trata da análise de um projeto de engenharia didática voltado para a leitura e produção do gênero crônica.

Participaram desse estudo 123 alunos matriculados no primeiro ano de três cursos técnicos ofertados na modalidade integrada de uma escola da rede federal localizada no munícipio de Timóteo/MG e seus respectivos professores da área de Códigos e Linguagens. O corpus foi constituído a partir dos registros da criação do projeto de engenharia didática, dos materiais empregados em sua implementação e dos textos produzidos tanto em meios convencionais quanto em um ambiente de escrita colaborativa.

A realização deste trabalho se faz relevante principalmente por aquilo a que se propõe um projeto de engenharia didática: submeter um fenômeno à experimentação e promover propostas de intervenção, tomando-se como base as reflexões realizadas e a organização sistemática de dados. É de fundamental importância destacar a participação ativa dos alunos ao longo do processo, a construção do conhecimento em grupo, a mediação do professor, o processo de avaliação contínua e participativa, bem como a reflexão sobre a prática pedagógica. Tal proposta resulta em um progresso contínuo da aprendizagem e na melhoria das ações didáticas. 


\section{ASPECTOS TEÓRICOS}

Nesta seção, tomando-se como base o aporte teórico-metodológico organizado pelos pesquisadores do Interacionismo Sociodiscursivo - ISD, propõese refletir sobre a engenharia didática e sua importância para as ações dos alunos e professores relativas ao desenvolvimento das capacidades de linguagem, bem como à elaboração de dispositivos didáticos voltados para a resolução de problemas relacionados ao ensino da língua materna. Também se discutirá o processo de avaliação escolar e suas diferentes dimensões, destacando-se o seu valor para o ensino e aprendizagem das atividades de linguagem.

\section{A engenharia didática e as práticas de linguagem: fundamentações epistemológicas}

Os referenciais de base da engenharia didática com foco nas práticas de linguagem inscrevem-se no quadro geral de uma psicologia da linguagem, orientada pelos pressupostos epistemológicos do interacionismo social. O Interacionismo Sociodiscursivo - ISD é uma corrente epistemológica e praxeológica, que pretende "analisar as condutas humanas como ações significantes, ou como "ações situadas", cujas propriedades estruturais e funcionais são, antes de mais nada, um produto da socialização" (BRONCKART, 1999, p.13, grifo do autor). Seu aporte teórico congrega a concepção de dialogismo bakhtiniana (2003), definido como um elemento constitutivo da própria linguagem, considerando-se que é no fenômeno social e ideológico da interação que a linguagem acontece; a concepção sociointeracionista de aprendizagem de Vygotsky (2005), segundo a qual as atividades cognitivas do indivíduo são determinadas pelas interações sociais, sendo ele um agente da transformação sócio histórica da comunidade na qual está inserido ao mesmo tempo em que nela se integra; e a Teoria do Agir Comunicativo, de Habermas (1989), para quem as ações verbais refletem a capacidade de interação entre sujeitos com vistas a atingir um objetivo previamente definido.

O ISD fundamenta-se na tese central de que "a ação constitui o resultado da apropriação, pelo organismo humano, das propriedades da atividade social mediada pela linguagem" (BRONCKART, 1999, p. 42, grifo do autor). Machado (2005) compreende as ações de linguagem

[...] como um conjunto de operações de linguagem, que constituem uma unidade e cujo resultado final é o texto. A responsabilidade da realização dessa ação pode ser atribuída a um indivíduo particular, que é movido por motivos e orientado por objetivos, no quadro de uma atividade social. (MACHADO, 2005, p. 252) 
Bronckart (1999) destaca que a ação de linguagem consiste essencialmente na prática dos diferentes gêneros discursivos disponíveis nas formações sociais. A apropriação dos gêneros constitui, nesse sentido, uma forma de socialização, ou seja, de o sujeito inserir-se nas atividades comunicativas humanas. A interação se dá por meio de textos empíricos, conforme observa o pesquisador:

O texto singular ou empírico, portanto, designa uma unidade concreta de produção de linguagem, que pertence necessariamente a um gênero, composta por vários tipos de discurso, e que também apresenta os traços das decisões tomadas pelo produtor individual em função da sua situação de comunicação particular (BRONCKART, 1999, p. 77).

Por considerar que todo texto empírico se constrói com base no modelo de um gênero e ainda que todo texto é pertencente a um conjunto de textos ou a um gênero, Bronckart (1999, p. 75) propõe adotar a expressão gênero de texto em vez de gênero do discurso, conforme designação de Bakhtin (2003).

Schneuwly \& Dolz (1999), partindo da hipótese de que as práticas de linguagem por meio dos gêneros incorporam-se nas atividades dos alunos, destacam a importância de a escola oportunizar a estes o domínio do gênero, tal como se dá o seu funcionamento nas práticas de linguagem de referência. Nesse sentido, as práticas de linguagem devem contemplar as diferentes dimensões sociais, cognitivas e linguísticas relativas ao funcionamento da linguagem no contexto de uma comunicação particular:

Toda ação de linguagem implica [...] diversas capacidades da parte do sujeito: adaptarse às características do contexto e do referente (capacidades de ação), mobilizar modelos discursivos (capacidades discursivas) e dominar as operações psicolinguísticas e as unidades linguísticas (capacidades linguístico-discursivas) (SCHNEUWLY, DOLZ, 1999, p. 6).

Esses pesquisadores pontuam, desse modo, a importância de se ensinar o texto, tomando como base os três fatores constitutivos do gênero: o contexto de produção, a organização textual e os aspectos linguístico-discursivos. Torna-se necessário, entretanto, refletir sobre a questão da transposição didática. Machado e Cristóvão (2006, p. 552) destacam que um conjunto de conhecimentos científicos passa por um processo de "deslocamentos, rupturas e transformações diversas", quando se pretende ensiná-los. As autoras apresentam três desafios relacionados às transposições didáticas: o primeiro diz respeito à transformação do conhecimento científico em conhecimento a ser ensinado e, posteriormente, em conteúdo de ensino; o segundo refere-se à autonomia dos objetos do conhecimento científico, cujos sentidos podem ser alterados no processo de transposição; e o terceiro refere-se à segmentação dos conteúdos/noções selecionados e à possibilidade de se construir uma proposta de ensino incoerente. 
Diante do desafio de se tornar viável o processo de transposição didática, os pesquisadores do Sociointeracionismo investiram na elaboração de um modelo didático de gênero, uma ferramenta que pudesse estabelecer a mediação entre os objetos de linguagem ensinados na escola e os que funcionam como referência. O modelo didático do gênero reside na prática da engenharia didática, conforme afirmam Pietro \& Schneuwly (2003), e se caracteriza por ser um referencial descritivo e metodológico voltado para a sistematização dos objetos de aprendizagem de um gênero. Ele busca definir, desse modo, "o objeto a ensinar e suas dimensões supostamente ensináveis" (PIETRO \& SCHNEUWLY 2003, p. 31). Ainda segundo os autores, a se considerar o modelo didático do gênero a ensinar como produto acabado, do ponto de vista de sua forma ou estrutura, ele em geral deve se organizar em cinco componentes essenciais: a definição geral do gênero; os parâmetros do

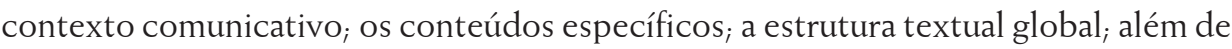
suas operações linguageiras e suas marcas linguísticas. (PIETRO \& SCHNEUWLY, 2003, p. 32-33)

Segundo os pesquisadores, a elaboração de modelos didáticos orienta-se por uma teoria mais abrangente da atividade de linguagem, que pode ser sintetizada conforme a seguinte tabela:

Tabela 1. Práticas Didáticas. Fonte: Pietro \& Schneuwly (2003, p. 33) - Adaptada por Adair Vieira Gonçalves.

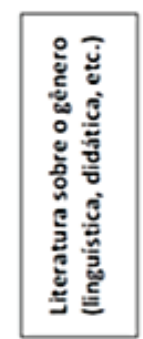

\section{SD}

$\mathrm{x}-\mathbf{i}$

$\mathrm{Z}+\mathbf{i}$
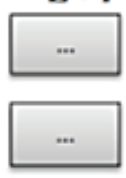

$+$
Sequência didática

'Relato oral"' $\mathrm{x}$

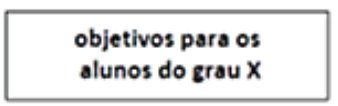

atividades para os

alunos do grau $X$

relato oral de alunos

do grau $X$

\section{Práticas sociais de referência}

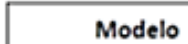

didático

"relato oral"

\section{Sequência didática}

"'Relato oral' $\mathbf{Z}$

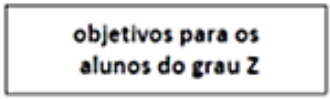

atividades para os

alunos do grau Z

relato oral de alunos

do grau Z
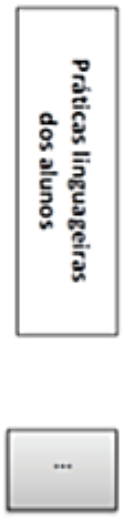

...

... 
Observe-se que esse modelo foi criado, considerando-se as dimensões ensináveis do gênero "relato oral". Tais categorias de análise têm como referência o modelo de produção e análise de textos proposto por Bronckart (1999), entre outras pesquisas. O modelo didático de gênero constitui, portanto, uma poderosa ferramenta de ensino, seja porque possibilita a construção de diferentes atividades de ensino e aprendizagem para um mesmo público-alvo, seja porque possibilita elaborar sequências didáticas de complexidade crescente em consonância com a zona de desenvolvimento proximal dos aprendentes.

Dolz e Scheneuwly (2004, p. 50) definem a sequência didática como "uma sequência de módulos de ensino, organizados conjuntamente para melhorar uma determinada prática de linguagem". Segundo esses pesquisadores, essa ferramenta de aprendizagem oportuniza aos alunos a experienciação de práticas de linguagem socialmente construídas e consolidadas nos diferentes gêneros textuais, de modo que eles possam reconstruí-las, internalizá-las e utilizá-las em diferentes contextos de comunicação. Esse processo deve levar em conta a interação de três fatores: as particularidades das práticas de linguagem que constituem objeto de aprendizagem; as capacidades de linguagem dos alunos e as estratégias de ensino evidenciadas na sequência didática.

Os pesquisadores observam que a organização de uma sequência didática voltada para uma evolução gradativa das capacidades iniciais dos alunos até o amplo domínio de um gênero deve obedecer às seguintes estratégias:

1. adaptar a escolha de gêneros e de situações de comunicação às capacidades de linguagem apresentadas pelos alunos;

2. antecipar as transformações possíveis e as etapas que poderiam ser transpostas;

3. simplificar a complexidade da tarefa, em função dos elementos que excedem as capacidades iniciais das crianças;

4. esclarecer com os alunos os objetivos limitados visados e o itinerário a percorrer para atingi-los;

5. dar tempo suficiente para permitir as aprendizagens;

6. ordenar as intervenções de maneira a permitir as transformações;

7. escolher os momentos de colaboração com os outros alunos para facilitar as transformações;

8. avaliar as transformações produzidas. (DOLZ \& SCHNEUWLY, 2004, p. 54).

Empenhados em desenvolver uma proposta de ensino da expressão oral e escrita da língua francesa, Dolz, Noverraz e Schneuwly (2004) desenharam a estrutura de base de uma sequência didática, que deverá conter as seguintes etapas: 
a) apresentação da situação, em que se procederá ao detalhamento da tarefa a ser realizada; b) produção inicial, que permitirá ao professor avaliar o domínio de conhecimento dos alunos e ajustar as atividades previstas nas sequências bem como promover ajustes que possam levar a um melhor domínio do gênero estudado; c) os módulos, os quais deverão conter um conjunto de atividades e exercícios que conduzirão a uma aprendizagem mais eficiente; e d) a produção final, em que o aluno poderá praticar os conhecimentos adquiridos e por meio da qual os professores poderão mensurar os progressos alcançados.

Machado e Cristóvão (2006, p. 555) ressaltam a importância do ensino da expressão oral e escrita por meio de sequência didática, uma vez que essa ferramenta: permite o desenvolvimento de um trabalho global e integrado; abrange tanto os conteúdos de ensino previstos em documentos oficiais quanto os objetivos específicos de aprendizagem; contempla atividades e suportes de exercícios variados; possibilita a integração de atividades de leitura, de escrita e de conhecimentos linguísticos, em consonância com um calendário pré-fixado; facilita a construção de programas integrados e sequenciais; propicia a motivação dos alunos, visto que traz em si uma explicitação dos objetivos específicos e gerais relacionados às propostas de ensino. As autoras refletem sobre a necessidade de que sejam produzidos materiais didáticos, que oportunizem a transposição didática dos conhecimentos científicos para contextos de ensino e aprendizagem condizentes com as capacidades dos aprendizes.

Pietro e Scheneuwly (2003, p. 45) asseveram que toda elaboração de sequências de ensino - a engenharia didática - é baseada num modelo do objeto a ensinar. Como produções realizadas no âmbito da engenharia didática, as sequências de ensino devem ser planejadas, submetidas à experiência e também à avaliação dos seus efeitos na aprendizagem. Em linhas gerais, a engenharia didática caracteriza-se como um modo específico de organização dos procedimentos metodológicos de pesquisas que tenham como fundamento a prática pedagógica. Como metodologia de pesquisa, ela se diferencia de métodos experimentais habituais na educação por seu método de validação, o qual se baseia no confronto entre uma análise a priori em que se realizou uma série de pressupostos e uma análise a posteriori, pautada em dados da efetiva realização.

Dolz (2016) define as linhas de base da engenharia didática como um campo particular da didática das línguas, que "organiza, transforma e adapta os saberes sobre a língua e as práticas discursivas para o ensino". Seu objetivo consiste na concepção de projetos escolares e na elaboração de "dispositivos, atividades, exercícios, materiais escolares e novas tecnologias da comunicação escrita, oral e audiovisual". 
(DOLZ, 2016, p. 241). Assim, ela deve organizar as formas sociais das práticas escolares, elaborar ferramentas de aprendizagens, orientar as intervenções e as práticas didáticas, além de promover pesquisas sobre as inovações implementadas.

Dolz (2016, p. 243-244) destaca as quatro fases que constituem um projeto de engenharia didática: análise prévia do trabalho de concepção; concepção de um protótipo de dispositivo didático; experimentação; e análise a posteriori.

A análise prévia do trabalho de concepção tem como objetivo o conhecimento dos objetos de ensino a partir de um quadro teórico adotado pelo pesquisador e dos conhecimentos didáticos relacionados ao objeto de estudo. Além disso, deve compreender uma avaliação das capacidades dos educandos e dos desafios que determinam sua evolução. Nessa fase, o pesquisador deverá se incumbir de elaborar a sequência didática a ser aplicada, estabelecer uma previsão das ações e dos comportamentos dos alunos durante a fase de experimentação, além de explicitar como as atividades propostas propiciarão a aprendizagem almejada. Além disso, deverá estabelecer, por meio de hipóteses, o processo de validação fundamentado na confrontação entre as análises a priori e a posteriori.

A segunda fase trata da concepção de um protótipo de dispositivo didático, que deverá se constituir de uma produção inicial com uma série de oficinas e atividades que permitam avaliar as capacidades dos alunos, bem como de uma produção final que possa mensurar os efeitos do ensino. Tais ações serão executadas de forma mais eficiente por meio do desenvolvimento de sequências didáticas, que oportunizem ao aluno o domínio de uma prática de linguagem (re)configurada em um gênero de texto, de modo que ele possa adaptá-la a uma situação de comunicação específica.

A experimentação consiste da aplicação da sequência didática elaborada na fase anterior com vistas à verificação das hipóteses levantadas na análise preliminar. Para Machado (2002, p. 206), a experimentação pressupõe "a explicitação dos objetivos e condições de realização da pesquisa à população de alunos que participará da experimentação; o estabelecimento do contrato didático; a aplicação do instrumento de pesquisa; e o registro das observações feitas durante a experimentação". Nesse contrato didático, é fundamental que o professor tenha consciência de que ele não deve interferir explicitamente na resolução dos problemas propostos, entretanto compete a ele mediar a aprendizagem, oferecendo ao aluno as condições ideais para sua participação ativa nas atividades propostas na sequência didática.

A última fase, a da análise dos resultados, permite confrontar as conclusões elaboradas na análise prévia com as constatações evidenciadas na aplicação da sequência didática. Assim é possível estabelecer um demonstrativo dos resultados obtidos, em que se evidenciem as contribuições para a superação de um problema 
bem como os limites do dispositivo criado, de modo que o objetivo da pesquisa possa ser validado.

Dolz (2016, p. 250-251) destaca a importância das atividades escolares na aprendizagem e apresenta sete princípios basilares para a concepção e elaboração de exercícios inovadores, com foco nos pressupostos da engenharia didática: permitir ao aluno que passe pela atividade da linguagem; considerar a Zona de Desenvolvimento Proximal do aluno (ZDP); garantir uma dinâmica que vai da elementarização para aprender até a integração dos elementos novos na totalidade do texto; fabricar as ferramentas para o aluno por um movimento progressivo de devolução; diversificar e articular as tarefas; antecipar as interações e explicitar os conceitos e comportamentos a desenvolver; respeitar a escolha do aluno.

Tais princípios são fundamentais se quisermos que os alunos experienciem situações de comunicação as quais façam sentido para si e lhes permitam participar ativamente da construção do conhecimento. Como mediador desse processo, o professor deve observar as capacidades iniciais dos alunos, bem como planejar e propor atividades de linguagem diversificadas e articuladas que atendam aos diferentes estilos de aprendizagem, despertem a motivação e a superação das dificuldades. Além disso, deve agir no sentido de apresentar propostas que favoreçam as interações e que oportunizem aos alunos escolhas que lhes garantam o desenvolvimento da própria linguagem e, progressivamente, a conquista de sua própria autonomia enquanto leitor e produtor de textos.

Em síntese, o trabalho com um projeto de engenharia didática oportuniza ao professor engenheiro sistematizar um conjunto de procedimentos metodológicos o modelo didático de gênero -, que lhe permitam uma ação investigativa por meio da qual será capaz de associar a ação pedagógica com os pressupostos teóricos a ela subjacentes. As atividades desenvolvidas por meio de sequências didáticas devem partir de uma concepção de aluno como sujeito ativo, reflexivo e autônomo, cabendo ao professor atuar como mediador da aprendizagem. Assim, nesse processo de construção do conhecimento, professor e alunos terão a oportunidade de refletir sobre os objetos de conhecimento, redirecionando e ressignificando a aprendizagem. Torna-se relevante também a divulgação dos resultados do projeto implementado, de modo que ele possa se configurar como referencial para o desenvolvimento de novas propostas de ensino.

\section{Avaliação e regulação como processo construtivo da aprendizagem}

Nesta subseção, será apresentada uma breve reflexão sobre os caminhos da avaliação da aprendizagem, dada sua importância no processo de construção 
do conhecimento. Como instrumento, a avaliação permite que os envolvidos no trabalho, professor e aluno, reflitam sobre os objetos de conhecimento, bem como promovam redirecionamentos e ressignificações do que está sendo ensinado e aprendido. Isso coaduna com o que Dolz (2016) propõe ao dizer que a engenharia didática organiza, transforma e adapta os saberes. Para prosseguir por tais passos, é necessário que haja constantemente a avaliação do e no processo.

Hoffman (2009) postula que, na construção do conhecimento, deve-se estabelecer "um processo de permanente troca de mensagens e significados, um processo interativo, dialógico, espaço de encontro e de confronto de ideias entre educador e educando em busca de patamares qualitativamente superiores de saber". (HOFFMAN, 2009, p. 76). Nesse sentido, entende-se que, para que esse processo seja deflagrado, é necessária a existência de avaliações diferenciadas. Entretanto é preciso deixar claro que diferenciar não está atrelado somente a observar o aluno por meio de diferentes tarefas como trabalhos em grupo, apresentação, exercícios no caderno e testes, acreditando que isso signifique contemplar o aprendizado dos alunos. Diferenciar significa, ainda de acordo com a autora, "fazer encaminhamentos pedagógicos diferentes de acordo com os percursos individuais, sem deixar de dinamizar o grupo de desenvolver um trabalho coletivo." (HOFFMAN, 2009, p. 98). É a visão de avaliação enquanto mediação. Essa vertente considera o ponto de vista de Vygotsky (2005), em que o sujeito avança de um nível em que está para outro, pela mediação da linguagem (pedagógica) ou pela mediação do outro. A avaliação é imprescindível para que esse processo de avanço ocorra.

A prática da avaliação como mediação, contudo, não é uma realidade presente em todas as salas de aula deste país. Há outras e possíveis formas de avaliar numa visão mais tradicional que são encontradas no sistema de ensino brasileiro. Neste ponto, vale resgatar esse passado recente da avaliação.

A avaliação deve ser compreendida a partir de seu histórico. O modelo tradicional de avaliação da aprendizagem está fortemente relacionado ao desenvolvimento das teorias tecnicistas e comportamentalistas que ganharam importância, principalmente, durante a década de 60. Elas buscavam pela avaliação, julgar a efetividade do processo de aprendizagem de acordo com os "comportamentos esperados". Por muito tempo, foram dedicados esforços à produção de testes, inventários, questionários, fichas de registro de comportamento etc. A avaliação da aprendizagem assumiu, durante décadas, a identidade de um instrumento para análise de desempenho final.

É a partir desse modelo que foram desenvolvidas muitas das ferramentas de avaliação de aprendizagem disponíveis na atualidade. A predominância de 
instrumentos de verificação quantitativa de aprendizagem reflete, no fundo, a concepção mecanicista de avaliação: testes de múltipla escolha, ferramentas de verificação quantitativa da participação etc. Dentro do modelo tecnicista, destacase o trabalho de Tyler (1949), um dos primeiros teóricos do tema, que considerava a avaliação educacional como a comparação constante entre os desempenhos dos alunos e os objetivos previamente definidos.

O trabalho de Bloom, Hastings e Madaus (1971) influenciou especialmente o planejamento educacional de várias gerações. Nele os autores sugerem três funções para a avaliação: diagnóstica, formativa e somativa. A avaliação diagnóstica ocorre antes e durante o processo de aprendizagem, visando a agrupar alunos, no primeiro momento, de acordo com suas dificuldades e, no final, identificar se houve, ou não, progresso em relação à assimilação dos conteúdos. A avaliação formativa é a que ocorre ao longo do processo de aprendizagem, com os objetivos de: corrigir falhas do processo educacional, prescrever medidas alternativas de recuperação das falhas desse processo; e prescrever medidas alternativas de recuperação das falhas de aprendizagem. Por sua vez, a avaliação somativa ocorre no fim de um processo, com claros objetivos de mensuração de resultados.

Não se pode esquecer de que o foco da atuação do professor dentro do modelo tecnicista era o de estruturar o conteúdo de forma a facilitar a sua absorção pelos alunos. O conceito de avaliação formativa, por exemplo, é muito citado, mas confundido com o conceito de mera avaliação contínua (isto é, aquela que é realizada ao longo do processo de aprendizagem). Segundo Perrenoud (1999) e Mazzeto (2003), uma avaliação pode ser contínua sem ser formativa. A verdadeira avaliação formativa é a que contribui para a individualização dos processos de aprendizagem, e não apenas as que são realizadas em vários momentos do processo de aprendizagem.

A avaliação formativa privilegia as diversidades individuais das diferentes maneiras de aprender dos estudantes. Ela proporciona também a extensão, a diversificação e pluralização dos percursos de aprendizagem. Além disso, permite ao professor elaborar e diversificar as estratégias pedagógicas, formular diversos processos de ensino e de avaliação, articular e aplicá-los na aula, ajustando-os em função do nível de aprendizagem dos alunos; enfim, permite a integração de material pedagógico diversificado.

Hadji (2001) defende que a avaliação formativa tem o objetivo de fazer com que os estudantes evoluam em relação ao estágio em que se encontram. Os problemas detectados nas produções escritas, por exemplo, não seriam faltas a 
serem condenadas, mas fonte de informação para o professor, cujo intento é analisar a produção e a situação do aluno.

A avaliação deve ser diversificada, por isso Armstrong (2004) destaca que não se deve descartar a avaliação formativa e a avaliação somativa. No caso da primeira, ela é uma "avaliação para o aprendizado" e acontece continuamente, na troca de informações entre o professor e o aluno, nos retornos de atividades de casa, de um atendimento individual sobre as atividades, de modo que ocorra um feedback em pontos a serem melhorados. Já a avaliação somativa acontece sempre ao final de uma etapa ou bimestre ou de um período estabelecido pelo professor, em que esse conjunto de informações é avaliado em forma de trabalhos, projetos, testes, provas etc. É medida por meio de nota. "Na avaliação formativa, o papel do professor é o de treinador, de assistente, ao passo que, na avaliação somativa, esse papel é o de um juiz." (ARMSTRONG, 2004, p. 8).

Nas diferentes formas de avaliação, é possível pensar na atribuição proposta por Dolz (2016), quando este diz o que a engenharia didática pode proporcionar, ou seja,

visa a conceber tecnicamente as tarefas e as ações dos alunos para aprender, coordenar as intervenções dos professores e elaborar dispositivos suscetíveis de resolver os problemas de ensino da língua. (...) Também está encarregada de inventar ferramentas para facilitar as aprendizagens e de orientar as intervenções e os gestos profissionais do professor. (DOLZ, 2016, p. 240-241).

Assim, observa-se que, para o trabalho de professor e aluno se efetivar eficazmente, a prática da avaliação deve ser considerada ao longo do processo: avaliações diagnósticas das primeiras produções para que sejam identificados o que foi suficiente e o que precisa ser aperfeiçoado, o que requererá a elaboração de intervenções e ferramentas para resolver os problemas, sendo assim de suma importância, por exemplo, para a construção do modelo didático de gênero; e avaliações formativas que ofereçam o feedback de todo planejamento desenvolvido e implementado em várias fases de aplicação das sequências didáticas.

Acrescente-se a essa modalidade a autoavaliação, uma situação de aprendizagem que permitirá ao estudante refletir sobre sua produção, repensá-la e reformulá-la fazendo os ajustes necessários, de modo a desenvolver a sua própria autonomia no processo de construção do conhecimento. Além disso, ela contribui para que a avaliação alcance uma dimensão mais globalizante, com a confluência de diferentes perspectivas, que envolvem tanto a ação do aluno quanto a do professor, entre outros agentes. 
O conceito de regulação é outro ponto pertinente para descrever o processo de interação social envolvido nos processos de avaliação. De acordo com Perrenoud (1999), regulação é o conjunto das operações metacognitivas do estudante e de suas interações com o meio que alteram seus processos de aprendizagem no sentido de um objetivo definido de domínio.

$\mathrm{Na}$ interação com o meio, o estudante recebe "informações sobre o seu desempenho numa ação" (BLACK \& WILIAM, 1998), podendo apresentar reações diferentes ao perceber o desnivelamento entre dois níveis de referência, aquele que ele atribui à mensagem recebida e aquele que ele associa ao estado presente. Diante da mensagem recebida, o estudante poderia levantar a questão: "há diferença entre os dois níveis?"; ou "qual é a aproximação entre eles?"; ou ainda "o que eu devo fazer para chegar lá?". Sadler (1989, apud BLACK \& WILIAM, 1998) propõe que a função formativa seja atribuída ao feedback somente no último caso. A mensagem que respalda a validação dessa terceira resposta, como sendo a única de caráter formativo, estabelece a valorização da autorregulação do processo de aprendizagem ou autoavaliação.

Para este trabalho, assume-se como pertinente o conceito de avaliação formativa, considerando-se que esse modelo de avaliação compreende todo o processo: no início, tem valor diagnóstico e, ao longo do processo, possibilita um redimensionamento das ações a partir do desempenho dos alunos, adquirindo um caráter eminentemente formativo. Já na autoavaliação, parte da avaliação formativa, o aluno percebe-se e tende a avançar quando ele se propõe a fazer os ajustes necessários para atingir o próximo nível.

\section{METODOLOGIA DE PESQUISA}

A pesquisa que originou este artigo inseriu-se no quadro do Interacionismo Sociodiscursivo e pretendeu discutir sobre a construção de um projeto de engenharia didática para o ensino e aprendizagem do gênero textual crônica, cuja implementação nos permitisse avaliar o desenvolvimento das capacidades de linguagem de alunos do primeiro ano do ensino integrado de uma escola da rede federal de ensino. Considerou-se, para isso, a seguinte pergunta-chave: como avaliar o desenvolvimento das capacidades de linguagem de alunos do primeiro ano do ensino integrado, engajados em um projeto de engenharia didática sobre a leitura e produção do gênero textual crônica? Partiu-se da hipótese de que a criação e implementação de dispositivos de ensino, a aplicação de avaliações formativas e as mediações realizadas no âmbito da engenharia didática maximizam 
o desenvolvimento da aprendizagem. Objetivou-se verificar o desenvolvimento das capacidades de linguagem dos alunos a partir de instrumentos avaliativos aplicados no transcorrer da implementação das sequências didáticas.

A orientação metodológica adotada é a da pesquisa-ação, com vistas a gerar informações e conhecimentos de uso efetivo no nível didático, de modo a promover condições para ações e transformações no ensino da língua/linguagem. O corpus analisado contemplou uma produção inicial que serviu de referência para organização do modelo didático de gênero e das sequências didáticas; uma produção textual e sua refacção, ambas desenvolvidas em um ambiente de escrita colaborativa; os respectivos processos avaliativos realizados pelo professor e pelos alunos; e a autoavaliação.

Os resultados apontaram para a experienciação das práticas de leitura e produção do gênero textual crônica, que oportunizaram a ação sobre o texto, maior interação entre professores, alunos e objetos de ensino; bem como o desenvolvimento das capacidades de linguagem. Refletiram também o engajamento em um projeto de engenharia didática, que permitiu aos docentes uma investigação sobre a própria prática e o aprimoramento desta, no sentido de oportunizar aos alunos maior domínio quanto ao uso do gênero tanto no ambiente acadêmico quanto em suas práticas sociais de referência. Tal pesquisa se justifica, pois oportuniza maior reflexão e compreensão de como a prática de leitura e escrita pode contribuir para melhor desenvolvimento das capacidades de linguagem, se for desenvolvida no âmbito de um projeto de engenharia didática, que explore os gêneros textuais, o modelo didático de gênero e as sequências didáticas como metodologia de ensino e pesquisa.

\section{O PROJETO DE ENGENHARIA DIDÁTICA: APRESENTAÇÃO E DESCRIÇÃO DOS DADOS}

O projeto de engenharia didática aqui relatado resultou dos esforços de uma equipe de professores da área de códigos e linguagem, da rede federal de ensino, que se engajaram no desenvolvimento de uma proposta interdisciplinar de leitura e produção do gênero textual crônica para alunos do primeiro ano do ensino integrado. A implementação desse projeto tinha como principais objetivos: fazer uma análise diagnóstica das capacidades de linguagem dos alunos recém-ingressos no ensino integrado; elaborar um modelo didático do gênero textual crônica; construir as sequências didáticas a serem implementadas no transcorrer do projeto; proceder à avaliação formativa ao longo do processo; coletar e analisar insumos que 
pudessem contribuir para a melhoria dos procedimentos didáticos e consequente aprendizagem; promover o processo de autoavaliação junto aos alunos; divulgar os resultados por meio de congressos e revistas especializadas. A escolha do gênero textual crônica ocorreu em cumprimento das atividades que seriam desenvolvidas para a Olimpíada de Língua Portuguesa e também pelo fato de esse conteúdo programático ser constitutivo do planejamento de ensino da série em questão.

A organização e implementação do projeto fundamentou-se nas quatro etapas previstas para um projeto de engenharia didática e nos sete princípios que orientam a concepção e elaboração de dispositivos didáticos em conformidade com os pressupostos da engenharia didática apresentados por Dolz (2016). O ponto de partida para sua elaboração foi a organização e implementação de uma sequência didática, que culminou com uma produção textual e ofereceu importantes insumos para uma avaliação diagnóstica. Observe-se que este projeto, na verdade, é a segmentação de uma proposta mais abrangente, que tem como foco o desenvolvimento das capacidades de linguagem do aluno, de forma contínua e globalizante.

A implementação do projeto ocorreu a partir de quatro sequências didáticas inter-relacionadas, que contaram com a participação de 123 alunos do primeiro ano do ensino integrado, divididos em três turmas. Foram planejados vinte e oito encontros presenciais, constituídos de atividades realizadas em classe e extraclasse, perfazendo um total de sessenta e uma horas trabalhadas. Não foram computadas nessas horas as atividades extraclasses de correção de textos e de avaliação a cargo do professor. As atividades de idealização e execução do projeto foram assim desenvolvidas:

Tabela 2. Idealização e construção de um projeto de engenharia didática.

$1^{\text {a }}$ Fase: Análises preliminares

\begin{tabular}{l|l} 
Encontros: 05 & Carga horária: $10 \mathrm{~h}$
\end{tabular}

Procedimentos:

- Avaliação diagnóstica com base em produção textual realizada pelos alunos.

- Definição da proposta de trabalho, tomando-se como base os referenciais da Olimpíada da Língua Portuguesa Escrevendo o Futuro $5^{\text {a }}$ edição - 2016.

- Leitura e análise das informações e do material didático disponibilizados no site da Olimpíada de Língua Portuguesa, relacionados ao gênero textual crônica e às sugestões de sequências didáticas propostas.

- Elaboração de um modelo didático do gênero textual crônica.

- Levantamento de materiais didáticos diversificados (diferentes textos multimodais, filmes, músicas etc.), a serem utilizados na construção dos objetos de ensino. 
$2^{\text {a }}$ Fase: Construção de protótipos de dispositivos didáticos

\begin{tabular}{l|l} 
Encontros: 05 & Carga horária: $15 \mathrm{~h}$
\end{tabular}

Procedimentos:

Planejamento e implementação das seguintes sequências didáticas:

- Oficina "Fotografia fácil".

- O gênero textual crônica: circulação sócio histórica, funcionalidade, conteúdo temático, estilo e composicionalidade.

- Leitura e análise da coletânea de textos intitulada "Crônicas da Cidade Amada", baseada no filme homônimo, dirigido por Carlos Hugo Christensen.

- Escrita colaborativa a partir do tema "O lugar onde vivo". Produção individual de texto na plataforma Google Drive. Reescrita a partir de comentários críticos feitos pelos integrantes da equipe na plataforma e de correções do professor.

$3^{\mathrm{a}}$ Fase: Experimentação

\begin{tabular}{l|l}
\hline Encontros: 12 & Carga horária: $24 \mathrm{~h}$
\end{tabular}

Procedimentos:

- Participação em uma oficina de fotografia, cujo produto final fosse a apresentação, por parte dos alunos, de uma imagem sobre algum aspecto da cidade em que vivem, bem como reflexão sobre a mesma, que representasse o seu olhar, considerando-se a sua condição de leitores e de cidadãos.

- Realização de leitura e análise de crônicas, com vistas à compreensão dos seus aspectos temáticos, composicionais, estilísticos e sua dimensão pragmático-social.

- Apreciações literárias a partir de crônicas de diferentes autores com vistas à fruição e reelaboração da realidade.

- Produção de uma crônica que evidenciasse um olhar sobre a cidade, conforme a proposta da Olimpíada de Língua Portuguesa, utilizando, para tal, um ambiente de escrita colaborativa.

$4^{\mathrm{a}}$ Fase: Avaliação dos resultados

\begin{tabular}{l|l} 
Encontros: 06 & Carga horária: $12 \mathrm{~h}$
\end{tabular}

Procedimentos:

- Avaliação processual a partir dos seguintes instrumentos e ações: exercícios e produções individuais; debates; reuniões de equipe; apresentação de trabalhos; leitura e análise dos textos produzidos no ambiente virtual de escrita colaborativa; apreciação crítica dos textos feita pelos alunos no Google Drive; e respostas ao questionário de autoavaliação.

A primeira fase consistiu de dois movimentos de pesquisa distintos, mas que se integravam em uma única proposta: um relacionado ao levantamento dos pressupostos teóricos subjacentes ao gênero textual crônica, e outro relativo à seleção de materiais didáticos, que servissem como referenciais do protótipo de dispositivos didáticos a serem desenvolvidos. Essa tarefa favoreceu o desenvolvimento de um referencial cognitivo norteador da pesquisa em seus aspectos tanto epistemológicos quanto metodológicos. 
Os dispositivos didáticos foram produzidos em conformidade com a estrutura de uma sequência didática proposta por Dolz, Noverraz e Schneuwly (2004). As atividades foram desenvolvidas sob um viés interdisciplinar, de modo a oportunizar aos alunos o exercício da linguagem de forma interativa e em situação real de uso. As atividades foram planejadas e estruturadas observando-se uma continuidade de desafios propostos a partir de ações diversas e diferenciadas, que permitissem aos alunos o desenvolvimento do senso de participação, de socialização e de fruição.

$\mathrm{Na}$ terceira fase, passou-se à implementação das sequências didáticas, cuja realização dependeu de: explicitação dos objetivos e das condições de realização do projeto; mediação pedagógica e observância à Zona de Desenvolvimento Proximal dos aprendentes; apresentação de estratégias que garantissem a eficácia e a viabilidade das atividades pedagógicas; conscientização dos alunos quanto à necessidade de realização das atividades; e atuação conjunta entre os pares, autonomia na tomada de decisões, experimentação, reorganização das atividades e (re)adequação a um resultado satisfatório.

A avaliação apoiou-se em um conjunto de informações coletadas na experimentação, por meio de registros orais e das produções escritas. Optou-se, principalmente, por um modelo de avaliação formativa (qualitativa), que garantisse a mediação e as intervenções pedagógicas no transcorrer das atividades. Assim, em cada encontro, professores e alunos revisaram as ações previstas no projeto, observando-se as etapas cumpridas com sucesso e aquelas que necessitavam de adequações ou de maior empenho no cumprimento das tarefas. Para a produção das crônicas, utilizou-se o Google Drive. ${ }^{1}$ Tal plataforma oportunizou que os alunos, divididos em pequenos grupos, não só lessem os textos uns dos outros, como também apresentassem suas considerações a respeito das produções dos colegas. Essa ação enriqueceu muito o trabalho de revisão textual e a apresentação de uma segunda versão, visto que passou pelo crivo não só do professor como também dos próprios colegas da equipe. Ao final de todo o processo, os alunos submeteram-se a uma autoavaliação, em que puderam refletir sobre a sua participação nas atividades e sobre as situações de ensino e aprendizagem.

1. Neste trabalho, empregaremos a expressão Google Drive para nos referirmos não só à plataforma de armazenamento, mas também à suíte de escritório que ela passou a incorporar e que, anteriormente a 2012, era conhecida como Google Docs. O conceito de computação em nuvem e as capacidades de colaboração associadas às aplicações disponíveis também nos permitirão reconhecer o Google Drive como um ambiente de escrita colaborativa. 


\section{APRESENTAÇÃO E DISCUSSÃO DOS RESULTADOS}

Os dados ora apresentados partem da hipótese de que a escrita colaborativa, como estratégia integrante de um projeto de engenharia didática, é também um espaço de interação com os objetos do conhecimento, que favorece a mediação da aprendizagem. Essa mediação é de caráter formativo na medida em que é um processo de autorregulação da aprendizagem. Certamente, como se verá, a interação entre pares assume lugar central, mas não é ela somente que proporciona oportunidades de mediação.

Nesta seção, apresentam-se dados relativos às terceira e quarta fases do projeto de engenharia didática empreendido. Inicialmente, passa-se a uma exposição e discussão dos dados referentes à avaliação das crônicas produzidas na última etapa da terceira fase. As etapas anteriores dessa mesma fase de experimentação serão contempladas durante a discussão dos resultados da autoavaliação, que, por sua vez, integra a quarta fase. Em seguida, propõe-se uma reflexão sobre os dados levantados no processo de autoavaliação feita pelos discentes.

\section{Avaliação da crônica}

A última atividade da terceira fase constituiu-se da produção de uma crônica a fim de que os alunos participassem da Olimpíada de Língua Portuguesa. Em razão disso, o ponto de partida foi um olhar sobre a cidade. Os 123 alunos foram organizados, seguindo a ordem de chamada, em grupos com quatro integrantes; instruídos a elaborar a primeira versão de sua crônica; e, por meio da ferramenta "comentários" do Google Drive, elaborar ao menos três comentários em cada uma das crônicas de seus colegas de grupo. Dessa forma, esperava-se que cada aluno elaborasse ao menos nove comentários em diferentes crônicas e recebesse, em contrapartida, outros nove comentários em sua crônica. Para viabilizar as interlocuções, os alunos foram orientados a levar em conta os resultados das atividades anteriores realizadas na terceira fase de experimentação, o mesmo roteiro de revisão que empregariam em sua própria escrita, além de proceder com cordialidade em suas contribuições aos colegas.

A proposta de realizar a produção da crônica em um ambiente de escrita colaborativa buscava, justamente porque colaborativa, aumentar a interação dos alunos entre si e permitir-lhes atuar como autor e leitor. Ainda dentro da comunidade escolar, seus textos, durante o ato mesmo de produção, não seriam lidos somente pelos professores, os quais, quando de suas leituras, também apresentariam 
comentários aos textos. Conforme se verá mais adiante, a interação configurou-se em dialogia e favoreceu o desenvolvimento pessoal das habilidades linguajeiras.

Nos textos produzidos, chama atenção a quantidade de interações realizadas por meio dos comentários. A expectativa inicial era de uma dezena de interações por texto e, embora tenha havido faltas, ela foi alcançada em grande medida. Em casos extremos e desconsiderados os comentários apostos pelo professor, abrangeram cerca de noventa interações durante a realização das duas versões.

Seguindo os princípios de avaliação preconizados pela Olimpíada de Língua Portuguesa, os alunos tiveram suas crônicas avaliadas quanto aos cinco critérios por ela especificados, a saber: 1) Tema "O lugar onde vivo"; 2) Adequação discursiva; 3) Adequação linguística; 4) Marcas de autoria; e 5) Convenções da escrita. Também os mesmos pesos da grade de avaliação foram empregados. Esses critérios foram previamente apresentados e discutidos com os alunos. Quanto a cada uma das versões, os desempenhos de todos os alunos em cada um dos critérios foram organizados em uma planilha eletrônica. Isso permitiu que cada aluno recebesse, por meio de mala direta, os seus resultados individuais na primeira e na segunda versões de sua crônica. Como avaliação formativa e no próprio texto, juntamente com os demais colegas, os professores também realizaram comentários no sentido de ajustar a produção ao gênero pretendido. Nessa tentativa, diversificadas estratégias foram empregadas, conforme se vê em exemplos de comentários deixados em duas crônicas. Nas interações transcritas abaixo, as referências aos nomes dos alunos foram retiradas.

\section{Ex. 1 Comentário de um aluno a outro}

Na minha opinião, o local onde você vive não foi bem representado ao escrever uma crônica, já que ela surge de fatos cotidianos, e pelo seu texto, penso ter representado sua própria casa, e não um lugar que faça menção à cidade, assim podendo fazer, como característica de uma crônica, uma reflexão, uma crítica, ou humorizar.

Resposta: Sim, foi um problema para mim fazer a crônica por meio da cidade, então tentei focar na casa porque conheço mais. Vou tentar consertar isto na segunda versão.

Esse comentário exemplifica a preocupação do aluno quanto à própria finalidade da crônica: falar sobre "o lugar onde vivo". A essa mesma preocupação com a finalidade, juntam-se as possibilidades de reflexão, crítica ou humor. Uma interpretação possível para essas decisões pode indicar que o aluno, ao comentar 
o texto do colega, levou em conta o roteiro de revisão e a grade de avaliação. Há também a possibilidade de o aluno ter acionado as referências ao modelo didático da crônica construído durante as aulas e que focalizava a reflexão como propósito para o gênero crônica. Nesta mesma crônica, outros leitores também haviam destacado a necessidade de se alcançar maior aproximação com a temática proposta pela Olimpíada.

As respostas aos comentários não se revelaram muito frequentes. Embora não tenha sido feito um levantamento exaustivo no corpus de crônicas, nota-se que as interações tendem a acontecer entre alunos, conforme o exemplo acima e menos frequentemente entre alunos e professores. Ou seja, um aluno responde a outro e tende a não responder às interações iniciadas pelo professor ou a fazê-lo indiretamente por meio da edição do texto. É o que ocorre no seguinte exemplo:

\section{Ex. 2 Comentário do professor ao aluno}

\section{Trecho comentado:}

Chegando no portão percebo que ele está trancado, então grito minha tia: - TIA! TIA! Abre o portão. - E nada acontece, minha tia não aparece na janela nem na porta. E para piorar estou com muita vontade de ir ao banheiro.

Comentário: Faça a adequação verbal: você começou usando os verbos no passado e depois mudou para o presente. Faça a sua opção e a mantenha até o fim do texto.

O exemplo ilustra o trabalho de correção do professor, que a realiza por meio da indicação de uma inconsistência e do modo de saná-la. Em resposta, na segunda versão da crônica, há um ajuste do problema identificado, no entanto ele está limitado ao entorno do trecho comentado. Outros verbos no presente ainda permaneceram no texto. Na mesma produção, também outras dez questões foram identificadas e classificadas pelo professor. Porém, o maior esforço recai para a construção da narrativa, conforme se pode ver no exemplo abaixo:

\section{Ex. 3 Comentário do professor ao aluno}

Seu texto está bom, mas há algumas inconsistências que precisam ser melhoradas.

- Apresentação de aspecto do cotidiano local: não há nenhuma descrição da cidade onde a narrativa se passa; 
- Título: a confusão não parece tão evidente ou interessante no texto. Afinal sangue com sabão vermelho? Essa é a confusão?

- Casa fechada / casa aberta: tudo bem que o desespero faz isso, mas daí a forçar a fechadura quando a porta estava aberta?

- Sabão / sangue vermelho: relação muito superficial. Mas aqui está o mote para sua crônica. Imagine o que possa estar acontecendo lá dentro. Alguém assassinado. A porta trancada, polícia... para no final apresentar a confusão anunciada no título.

- Não há nenhuma passagem em que se proponha reflexão relacionada a algum problema. Tampouco seu posicionamento acerca de um problema mencionado. Isso pode ser evidenciado no texto, considerando a violência urbana, por exemplo. Tem sangue na sua narrativa.

Esse é o comentário final à leitura da primeira versão da crônica. A partir dele, é possível reconstituir o modelo didático trabalhado nas etapas anteriores e a tentativa de promover a aproximação a ele. As instruções para a elaboração da segunda versão ocorrem em forma de problemas sobre os quais o aluno deverá refletir quando da elaboração de seu texto. A avaliação assume o caráter formativo apontado por Black e William (1998, p. 48-49) na medida em que oferece subsídios para o aluno buscar um ajustamento a partir de sua reflexão pessoal, que se torna viável em face da explicitude das instruções. Além disso, o exemplo também evidencia a diversidade de estratégias empregadas nos comentários: alguns contêm instruções simples e levam diretamente à solução de um problema qualquer, outros exigem o trabalho reflexivo do aluno.

Ex. 4 Comentário do professor ao aluno

A segunda versão de sua crônica se enquadra nos padrões exigidos pela Olimpíada de Língua Portuguesa.

Você ainda cometeu erros de natureza gramatical, principalmente de pontuação e de acentuação das palavras.

Atente-se a eles a fim de evitá-los nas próximas propostas de produção textual.

Parabéns pelo empenho.

Ao encerrar a avaliação e o trabalho com as crônicas, o comentário acima constitui-se na palavra final do professor ao aluno. Assim como o exemplo anterior, essa avaliação também se enquadra nos parâmetros de uma avaliação formativa. Mais especificamente, o feedback é informação útil ao aluno para que ele execute 
ações corretivas em sua performance. Em termos concretos, juntamente com o comentário reproduzido acima, o professor fez destaques nos contextos em que ocorriam problemas de pontuação e de acentuação por ele mencionados.

Conforme já se começou a expor, as crônicas foram objeto de avaliação por meio da grade de desempenhos elaborada pela equipe organizadora da Olimpíada de Língua Portuguesa. Um nível de desempenho (N.0 a N.5) foi atribuído em uma escala de zero a cinco para cada um dos cinco critérios contemplados na grade: C.1: Tema "O lugar onde vivo"; C.2: Adequação discursiva; C.3: Adequação linguística; C.4: Marcas de autoria; e C.5: Convenções da escrita. Os gráficos abaixo sintetizam os desempenhos obtidos pelos alunos na primeira e na segunda versão de suas crônicas.

Gráfico 1. Turma 1: desempenhos na $1^{\mathrm{a}}$ e na $2^{\mathrm{a}}$ versão. Fonte: dados de pesquisa (2016).

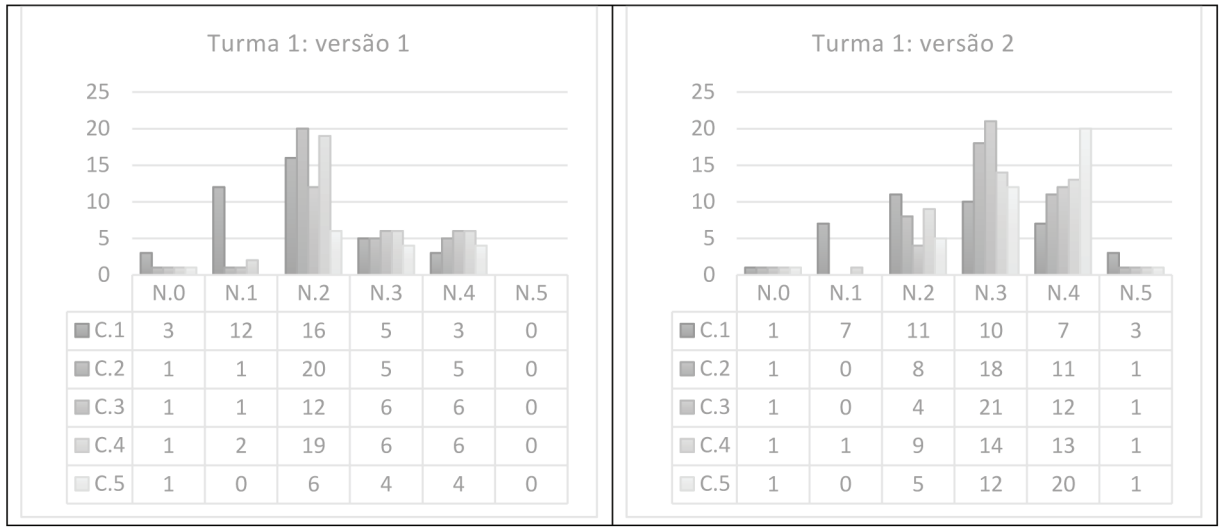

Tanto na primeira, quanto na segunda versão, há um aluno com nível zero em todos os critérios. Trata-se da única omissão identificada no conjunto de 123 alunos. Em linhas gerais, importa notar que, na primeira versão, encontramos maior quantidade de alunos concentrados no nível 2 de desempenho em todos os critérios, assim como a ausência de alunos avaliados no nível 5. Em contrapartida, na segunda versão, destaca-se uma maior quantidade de alunos nos níveis 3 e 4 de desempenhos, além do aparecimento de alunos no nível 5. Na passagem de uma versão a outra, nota-se que muitos alunos ainda encontraram problemas para ajustar sua crônica à temática local. Por outro lado, o critério 2 (Adequação discursiva) também contém preocupações com aspectos da realidade local, além de ocupar-se de elementos centrais para a constituição do gênero crônica. Nesse critério, houve sensível melhora: 30 dos 39 alunos passam a estar agrupados nos níveis 3 e 4 .

Quanto à segunda turma, são estes os dados: 
Gráfico 2. Turma 2: desempenhos na $1^{\mathrm{a}}$ e na $2^{\mathrm{a}}$ versão. Fonte: dados de pesquisa (2016).

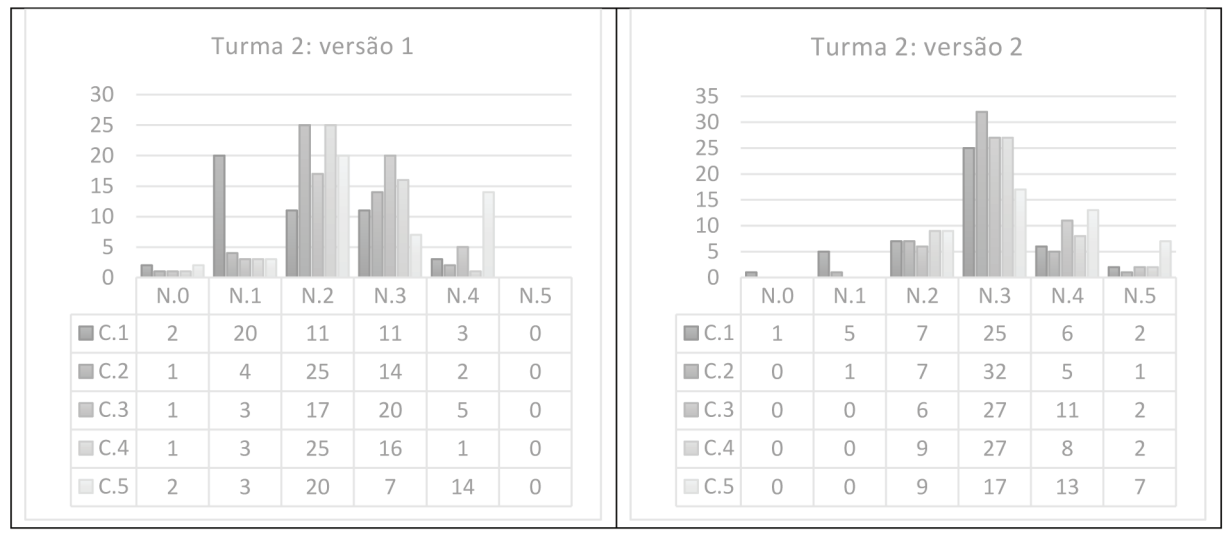

Novamente, observam-se progressos na passagem da primeira à segunda versão. Enquanto alguns alunos avançam do nível 2 para o nível 3, outros o fazem do nível 3 aos seguintes. O destaque recai para a adequação quanto à temática solicitada, aspecto que apresenta maiores mudanças. Dado que ele é central para a atividade conforme foi proposta, as mudanças necessárias nos textos para que os novos desempenhos fossem atribuídos não poderiam ser consideradas pequenas. Todavia, nesta turma, os avanços parecem ser menores que os observados na Turma 1.

Passemos, agora, aos índices de desempenho da turma 3:

Gráfico 3. Turma 3: desempenhos na $1^{\mathrm{a}}$ e na $2^{\mathrm{a}}$ versão. Fonte: dados de pesquisa (2016).

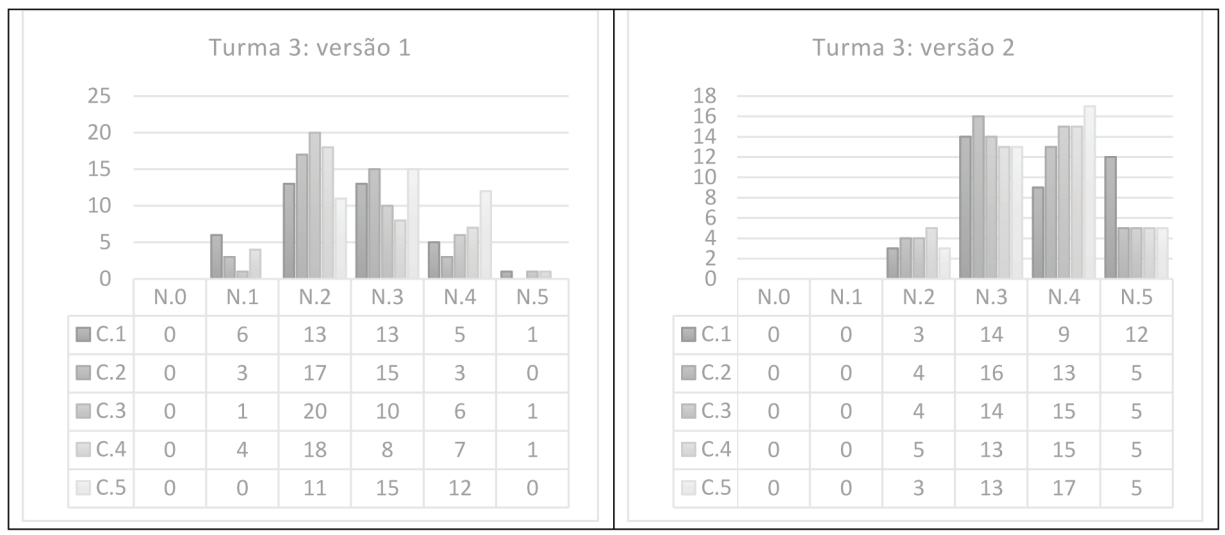

Essa última turma apresenta, desde o início, melhores resultados e, ao final do processo, consegue distribuir maior quantidade de alunos nos níveis 4 e 5 de desempenho. Mesmo assim, o fato de ainda haver alunos, por exemplo, no 
nível 3 quanto ao critério 5 (Convenções da escrita) significa a necessidade de continuar a desenvolver sistematicamente as atividades de reescrita. Assim como garantir que haja tempo suficiente para a ocorrência das aprendizagens (DOLZ \& SCHNEUWLY, 2004, p. 54).

\section{Questionários de autoavaliação}

Ao final do desenvolvimento das sequências didáticas apresentadas na seção anterior e para favorecer os processos de autoavaliação nela referidos, o grupo de professores apresentou aos alunos um questionário constituído por dez perguntas. As primeiras nove seriam respondidas por meio de uma escala de quatro níveis: ótimo, bom, regular e fraco. Na última questão, os alunos foram instados a comentar (a) os aspectos positivos em participar de atividades acadêmicas em um ambiente de escrita colaborativa e (b), os aspectos negativos dessa participação. Foram coletadas 119 respostas do grupo de 123 alunos.

A décima questão teve suas respostas analisadas por meio do aplicativo de análise qualitativa MaxQDA, um software para análise de dados qualitativos e métodos mistos de investigação, como entrevistas, artigos científicos, questionários, além de outras possibilidades. O primeiro procedimento de análise envolveu a codificação das respostas em grupos temáticos recorrentes, aqui nomeados: 1) Colaboração; 2) Ambiente; e 3) Realização do Trabalho. Para além dessas possibilidades interpretativas, foi identificado um conjunto de situações que, conquanto significativas, não se encaixavam nos recortes temáticos estabelecidos: a ausência de respostas à última questão, a negação da existência de aspectos negativos, ou a decepção com as notas auferidas na atividade.

Em síntese, o total de respostas discursivas recolhidas foi codificado da seguinte maneira:

Tabela 3. Codificação das respostas. Fonte: dados de pesquisa (2016).

\begin{tabular}{|l|r|r|}
\hline Grupo temático & Segmentos & \% Total no corpus \\
\hline Colaboração & 220 & $74,3 \%$ \\
\hline Ambiente & 37 & $12,5 \%$ \\
\hline Realização do trabalho & 13 & $4,4 \%$ \\
\hline Outras situações & 26 & $8,8 \%$ \\
\hline Totais & 296 & $100,0 \%$ \\
\hline
\end{tabular}

A Tabela 3 mostra a frequência de segmentos conforme sua pertença a cada um dos grupos temáticos recorrentes entre as respostas. Na terceira coluna, vê-se a porcentagem de cada grupo temático relativamente à totalidade dos segmentos 
analisados. Adiante, passa-se à leitura mais detalhada desses grupos temáticos. A Tabela 4, mostra a parcela de segmentos das respostas codificados no grupo temático Colaboração. A segunda coluna mostra a quantidade de segmentos rotulada sob um dado tema, a terceira coluna mostra a porcentagem desse tema no interior do grupo Colaboração e, finalmente, a quarta coluna mostra a porcentagem quanto à totalidade dos segmentos codificados.

Tabela 4. Codificação do grupo temático Colaboração. Fonte: dados de pesquisa (2016).

\begin{tabular}{|l|r|r|r|}
\hline \multicolumn{3}{|c|}{ Colaboração } \\
\hline Código & Freq. & \% Grupo & $\%$ Total \\
\hline Interação produtiva & 79 & $35,9 \%$ & $26,7 \%$ \\
\hline Mudança de percepção & 14 & $6,4 \%$ & $4,7 \%$ \\
\hline Comentários produtivos & 48 & $21,8 \%$ & $16,2 \%$ \\
\hline Engajamento dos alunos & 10 & $4,5 \%$ & $3,4 \%$ \\
\hline Interação conflituosa & 26 & $11,8 \%$ & $8,8 \%$ \\
\hline Comentários improdutivos & 16 & $7,3 \%$ & $5,4 \%$ \\
\hline Comentários obrigatórios & 5 & $2,3 \%$ & $1,7 \%$ \\
\hline Baixo engajamento dos alunos & 22 & $10,0 \%$ & $7,4 \%$ \\
\hline Totais & 220 & $100,0 \%$ & $74,3 \%$ \\
\hline
\end{tabular}

A temática da questão apresentada aos alunos causou um alto número de referências à interação. Nas respostas, a interação foi valorizada como positiva em 79 segmentos textuais. Combinados, os segmentos que indicam um traço positivo associado à interação (interação produtiva, mudança de percepção, comentários produtivos e engajamento dos alunos) respondem por $51 \%$ dos enunciados codificados no corpus.

Associados a essa valorização positiva, aparecem 14 segmentos relacionados a uma mudança de percepção quanto à própria linguagem. Como exemplos, encontramse enunciados tais como "e me desapontar com certos defeitos que não percebi sozinho, mas eram ridículos de evidentes", que aparece anotado como um aspecto negativo, mas revela essa mudança de percepção. $\mathrm{Na}$ mesma direção, apresenta-se o segmento "A colaboração através da crítica leva à percepção de detalhes positivos e negativos na sua própria escrita, posicionamentos que, até então, desconhecia". Tais mudanças de percepção quanto ao próprio estágio de desenvolvimento da linguagem revelam o caráter formativo do feedback proporcionado por colegas e professores ao trabalho do aluno e sugerem que o aluno pode ter tomado ações no sentido de aproximar-se do seu alvo (SADLER, 1989, p.140). Também evidencia 
um avanço do estágio de regulação externa assistida para o de autorregulação interna, em que o aluno percebe o potencial para promover as adequações no seu próprio texto. As mesmas ações corretivas estão implicadas neste enunciado "Um dos pontos positivos de uma escrita colaborativa é o aprendizado que se tira da escrita dos companheiros e também dos comentários", que também exemplifica a valorização atribuída à interação.

Pode-se observar, entretanto, que há um conjunto de observações que sinalizam expectativas não atendidas quanto à interação. Ela pode ser conflituosa: "você lidará com pessoas enroladas e esquecidas que acabam nos tirando a paciência", ou pode revelar a percepção da baixa utilidade dos comentários associada a um conflito de leituras: "O ponto negativo é que o colega pode não entender o que você quer dizer com o texto e propõe pontos de melhoras inexistentes".

Também numericamente importantes no corpus são as referências ao baixo grau de engajamento dos alunos nas atividades. Elas aparecem em segmentos tais como: "O ruim é que as vezes nós alunos fazemos por fazer, lemos as crônicas produzidas por nossos colegas de maneira desleixada e depois fazemos uns comentários nada a ver apenas para garantir nota". O baixo grau de engajamento pode ser um efeito das avaliações cumulativas, típicas da organização escolar e que prejudicam o funcionamento da avaliação formativa (SADLER, 1989, p.142). Todavia, apesar das constrições apresentadas pelos sistemas escolares, a maior frequência de atividades organizadas apenas em torno de uma avaliação formativa poderia vir a contrabalançar o efeito negativo das avaliações cumulativas.

Quanto à proposta de trabalho em um ambiente de escrita colaborativa, a Tabela 5 sintetiza as percepções dos alunos.

Tabela 5. Codificação do grupo temático Ambiente. Fonte: dados de pesquisa (2016).

\begin{tabular}{|l|r|r|r|}
\hline \multicolumn{4}{|c|}{ Ambiente } \\
\hline Código & Freq. & \% Grupo & \% Total \\
\hline Novas aprendizagens & 17 & $45,9 \%$ & $5,7 \%$ \\
\hline Transferência de aprendizagens & 6 & $16,2 \%$ & $2,0 \%$ \\
\hline Facilitação do trabalho & 7 & $18,9 \%$ & $2,4 \%$ \\
\hline Dificuldades de uso & 5 & $13,5 \%$ & $1,7 \%$ \\
\hline Dificuldades de acesso & 2 & $5,4 \%$ & $0,7 \%$ \\
\hline Totais & 37 & $100,0 \%$ & $12,5 \%$ \\
\hline
\end{tabular}

Embora com frequência mais baixa no corpus - apenas $12,5 \%$ contra os $74,3 \%$ das referências à colaboração - as referências ao ambiente de escrita colaborativa 
revelam a importância de a escola considerar em sua prática outros espaços de escrita, ainda desconhecidos do aluno que ingressa no ensino médio. $\mathrm{O}$ trecho "Hoje, eu passei a utilizar esse recurso [Google Drive] com muito mais frequência aprimorando assim meu processo de realização de trabalhos coletivos" exemplifica a referência a um novo aprendizado e a sua transferência para outras esferas da vida escolar. Nesse mesmo sentido, destaca-se este enunciado: "Além disso, a prática da escrita colaborativa acaba por auxiliar a realização de outros trabalhos, já que amplia nosso senso crítico e nossa capacidade de receber e trabalhar em cima das críticas que recebemos", que revela o papel das interações, mesmo as difíceis, como necessárias ao desenvolvimento pessoal. Há também certa expectativa futura: "assumo que atividades colaborativas possam nos preparar para o mercado de trabalho, nos incentivando a trabalhar em equipe, auxílio mútuo entre os membros".

Nas respostas, a preocupação quanto ao acesso à internet é identificada em dois segmentos. O domínio das ferramentas em si, conforme se vê em "Um aspecto negativo foi a dificuldade de começar a mexer com o Google Drive", aparece em outros cinco trechos. Ocorrências tais como essa servem de alerta para não se assumir que os alunos tenham já adquiridas as habilidades mínimas para a escrita em ambientes virtuais. Na mesma direção das dificuldades, há um conjunto de segmentos indicando outros problemas que podem ocorrer quanto à escrita colaborativa, conforme se vê na Tabela 6, abaixo:

Tabela 6. Codificação do grupo temático Realização do Trabalho. Fonte: dados de pesquisa (2016).

\begin{tabular}{|l|r|r|r|}
\hline \multicolumn{4}{|c|}{ Realização do Trabalho } \\
\hline Código & Freq. & \% Grupo & \% Total \\
\hline Prazos e organização & 8 & $61,5 \%$ & $2,7 \%$ \\
\hline Demandas ao professor & 5 & $38,5 \%$ & $1,7 \%$ \\
\hline Totais & 13 & $100,0 \%$ & $4,4 \%$ \\
\hline
\end{tabular}

Os segmentos identificados no grupo temático Realização do Trabalho revelam-se mais pertinentes para a gestão das atividades escolares em si. Como exemplo, o enunciado "Datas e Tempo. Por ser no computador, você acaba desviando o foco da atividade, consequentemente, perdendo tempo" indica tanto a dificuldade de organização pessoal para atender ao tempo escolar, quanto a percepção de que o uso do computador é em si uma fonte de dispersão para os alunos.

A interação também aparece como uma demanda do aluno quanto ao professor. Ela pode ser vista em: "Acho que faltou uma maior aproximação aluno/professor. 
Vejo que é algo difícil, tomando em conta a quantidade de alunos e o curto tempo, mas uma alternância de etapas de acordo com a turma para execução do trabalho poderia resolver". Além de apontar a maior aproximação como necessidade, há ainda demandas por mais clareza na exposição ou explicações sobre avaliação. É o que se vê em segmentos tais como: "Alguns tópicos confusos, algumas linguagens são complicadas, difíceis de compreender e maçantes. Isto atrapalhou um pouco o que poderia se ter de uma boa experiência com os textos" ou "A participação dos professores deveria ser mais intensa a fim de que a construção culminasse em um texto melhor estruturado, uma vez que, apesar de auxílios, os integrantes não possuem amplo conhecimento acerca do gênero, muito menos senso crítico". Nesse conjunto, pode-se reconhecer a busca por um feedback que seja útil do ponto de vista formativo (BLACK \& WILIAM, 1998, p. 55). A contraparte a essas demandas pode ser vista ainda na Tabela 4, que também revela serem as atividades de escrita colaborativa capazes de despertar "o interesse dos mais desinteressados" e "O fato de terem pessoas ao meu redor, dispostas a ajudar na escrita, correção e compreendimento [sic] dos textos, além do auxílio e intervenção dos professores dentro dos textos". Afirmações como essas podem sugerir que o feedback dado por meio das ferramentas disponíveis no ambiente de escrita colaborativa é um fator positivo a se considerar quanto ao desenvolvimento das habilidades linguageiras.

Por fim, retoma-se uma parcela do questionário que indica o ponto de vista dos alunos quanto às suas experiências com as atividades de escrita colaborativa. Conforme já se expôs, o questionário estava organizado em dez questões, sendo apenas a última de caráter dissertativo. Dois dos questionários não apresentavam qualquer resposta para os aspectos positivos no trabalho com a escrita colaborativa. No lado oposto, havia oito questionários sem respostas para os aspectos negativos e outras nove respostas que, ostensivamente, não identificavam aspectos negativos na atividade. Neste grupo, incluem-se enunciados como: "Não consigo pensar em um aspecto negativo proveniente desta atividade" ou "Eu não vejo nenhum aspecto negativo, pois neste ambiente um ajuda o outro". Foram identificados também sete segmentos em que o aluno se mostrava decepcionado com as notas. Por exemplo, "O ruim foi ter um grande esforço na realização do trabalho e o resultado não ter sido como o esperado". Uma interpretação possível para esse comportamento pode revelar, ainda que de forma indireta, certo grau de engajamento no trabalho. Caso contrário, não haveria decepção.

\section{CONCLUSÕES}

Neste trabalho, buscamos refletir sobre a construção de um projeto de engenharia didática para o ensino e aprendizagem do gênero crônica. Nossa tarefa 
foi verificar, por meio do projeto, o desenvolvimento das capacidades de linguagem de alunos do primeiro ano do ensino integrado. Todo trabalho inseriu-se no quadro teórico do Interacionismo Sociodiscursivo e buscou avaliar o desenvolvimento das capacidades de linguagem dos alunos, engajados em um projeto de engenharia didática sobre a leitura e produção de crônica? A hipótese se confirmou, pois a criação e aplicação de dispositivos de ensino e as intervenções realizadas potencializaram o desenvolvimento da aprendizagem, das capacidades linguageiras e oportunizaram a reflexão sobre a prática. Chamam a atenção as interações e a autoavaliação realizadas pelos alunos durante o processo. A maior parte das turmas envolvidas conseguiu avançar para o nível seguinte nos cinco critérios propostos. Todavia, o fato de estudantes ainda se apresentarem no nível três do critério de cinco (convenções da escrita) demonstra o trabalho intenso e sistemático que precisa continuar a ser desenvolvido.

As interações, o meio e o próprio objeto favoreceram a mediação da aprendizagem, permitindo o avanço na zona de desenvolvimento proximal (VIGOTSKY, 2005). A troca de informações e as interações oportunizaram aos estudantes uma reflexão sobre sua produção e a do outro. A partir dessas reflexões, muitos conseguiram avaliar o que produziram, buscando avançar para o texto ideal, para o modelo previamente apresentado no desenvolvimento das sequências didáticas. No questionário aplicado, observou-se ainda a importância da interação, do engajamento consciente do aluno nas atividades propostas, a identificação com o dispositivo elaborado no meio virtual, a compreensão do trabalho colaborativo. Vale ressaltar ainda a valorização dada à palavra do professor e a necessidade de interação com ele, revelando o discurso de autoridade esperado. Essa necessidade de interação ficou patente nos segmentos que os alunos se ressentem das instruções deixadas pelos professores, quer em quantidade, quer em qualidade. Por fim, o desenvolvimento dos sete princípios basilares propostos por Dolz (2016, p. 250-251) favoreceu a proposta apresentada e a obtenção de resultado positivo na apropriação e construção da escrita, da leitura, da atividade de linguagem dos alunos.

No que tange à escrita colaborativa, é importante ressaltar que as crônicas foram produzidas individualmente em atendimento às exigências da Olimpíada de Língua Portuguesa. As colaborações ocorreram no sentido de cada aluno apreciar criticamente os textos produzidos pelos colegas da equipe na qual estava inserido. É importante destacar que outras propostas de escrita colaborativa, em que ocorra a participação conjunta dos alunos em todas as etapas da elaboração de um texto único, podem apresentar resultados distintos dos obtidos não só quanto às decisões 
sobre o texto em si, mas também quanto à interação, negociações e cordialidade entre os pares.

\section{REFERÊNCIAS BIBLIOGRÁFICAS}

ARMSTRONG, D. (2004). Uma visão contemporânea da avaliação. Presença Pedagógica, Belo Horizonte, v. 10, n. 57, p.5-13, maio/jun.

BAKHTIN, M. M. (2003 ). Os gêneros do discurso. In: Estética da criação verbal. SP: Martins Fontes, p. 261-306.

BLACK, P.; WILIAM, D. (1998). Assessment and classroom learning. Assessment in Education, v. 5, n. 1, p. $7-73$.

BLOOM, B., HASTINGS; MADAUS, G.F. (1971). Handbook on Formative and Summative Evaluation of Student Learning. New York: McGraw-Hill Book Company.

BLOOM, B.; HASTINGS, J. T.; MADAUS, G.F. (1983). Manual de Avaliação Formativa e Somativa do Aprendizado Escolar. Tradução de Lílian Rochlitz Quintão. São Paulo: Livraria Pioneira Editor.

BRONCKART, J.-P. (1999). Atividade de linguagem, textos e discursos: por um interacionismo sócio-discursivo. São Paulo: Educ.

DOLZ , J.; SCHNEUWLY, B. (2004). Gêneros e progressão em expressão oral e escrita. Elementos para reflexões sobre uma experiência suíça (francófona). In: Gêneros Orais e escritos na escola. Campinas (SP): Mercado de Letras.

DOLZ, J. (2016). As atividades e os exercícios de língua: uma reflexão sobre a engenharia didática. D.E.L.T.A., nº 32.1, 2016, p. 237-260. Disponível em http://www.scielo.br/ pdf/delta/v32n1/0102-4450-delta-32-01-00237.pdf. Acesso em 30 out.

DOLZ, J.; NOVERRAZ, M.; SCHNEUWLY, B. (2004 ). Sequências didáticas para o oral e a escrita: apresentação de um procedimento. In: SCHNEUWLY, B.; DOLZ, J. e colaboradores. Gêneros orais e escritos na escola. Campinas-SP: Mercado de Letras.

HABERMAS, J. (1989). Consciência moral e agir comunicativo. Rio de Janeiro: Tempo Brasileiro.

HADJI, C. (2001). Avaliação Desmistificada. Porto Alegre: Artes Médicas.

HOFFMANN, J. (2009). Avaliar para promover: as setas do caminho. Porto Alegre: Mediação. 
MACHADO, A. R. (2005). A perspectiva interacionista sociodiscursiva de Bronckart. In: MEURER, J.L.; BONINI, A.; MOTTA-ROTH, D. (Orgs.). Gêneros: teorias, métodos, debates. São Paulo: Parábola Editorial. p. 237-259.

MACHADO, A. R.; CRISTOVÃO, V. L. L. (2016). A construção de modelos didáticos de gêneros: aportes e questionamentos para o ensino de gêneros. Linguagem em (Dis) curso, [S.1.], v. 6, n. 3, p. p. 547-573, out. 2010. ISSN 1982-4017. Disponível em: $<$ http://www.portaldeperiodicos.unisul.br/index.php/Linguagem_Discurso/article/ view/349/370>. Acesso em: $30 \mathrm{dez}$.

MACHADO, S. D. A. (2002). Engenharia didática. In: MACHADO, S. D. A. (org.). Educação Matemática: uma introdução. 2 ed. São Paulo: Educ. p. 197-208.

MEURER, J.L.; BONINI, A.; MOTTA-TOTH, D. (orgs). (2005). Gêneros, Teorias, Métodos e Debates. São Paulo: Parábola.

PERRENOUD, P. (1999). Avaliação: Da Excelência à Regulação das Aprendizagens - entre duas lógicas. Tradução de Patrícia Chittoni Ramos. Porto Alegre: Artes Médicas.

PIETRO, J.-F. de; SCHNEUWLY, B. (2003). Le modèle didactique du genre: un concept de l'ingénierie didactique. Les Cabiers Théodile n 3: Université Charles-de-Gaulle - Lille 3, jan. 2003, pp.27-53. Tradução de Adair Vieira Gonçalves.

SADLER, R. (1989). Formative assessment and the design of instructional systems. Instructional Science, v.18, n. 2, jun., p. 119-144.

SCHNEUWLY, B.; DOLZ, J. (1999). Os gêneros escolares: das práticas de linguagem aos objetos de ensino. Revista Brasileira de Educação. Rio de Janeiro: ANPED, mai/jun/jul/ ago, $n^{\circ} 11$.

TYLER, R.W. (1949). Basic principles of curriculum and instruction. Chicago: The University of Chicago Press.

VIGOTSKY, L. S. (2005). Pensamento e Linguagem. São Paulo: Martins Fontes.

Recebido: 10/01/2017

Aceito: 23/02/2018 